\title{
The Role of the International Code Council in the U.S. Building Regulation System and Green Building Construction $^{1}$
}

\author{
El rol del International Code Council en el sistema de regulación de la construcción en Estados \\ Unidos y en la construcción verde
}

David Walls ${ }^{(1)}$

(1)Executive Director of Sustainability Programs for the International Code Council. United States. dwalls@iccsafe.org

Received September 8th, 2014. Modified February 4th, 2015. Approved February 9th, 2015.

DOI: http://dx.doi.org/10.16924/riua.v0i41.782

\section{Palabras clave}

Códigos de construcción, documentos regulatorios, Estados Unidos, estándares, International Code Council.

\section{Resumen}

Este artículo abordará los componentes del International Code Council (ICC), una de las organizaciones más importantes en el desarrollo de los códigos de construcción de los EE.UU.: los códigos internacionales. Esta organización tiene la tarea de proporcionar a la industria de la construcción y a todos sus grupos de interés los documentos normativos, la formación, la certificación, la verificación y el plan de evaluación de los productos y de acreditación de servicios necesarios para lograr la construcción de edificios más seguros y sostenibles. Este artículo dará una mirada a los códigos de construcción en Estados Unidos, a la ICC y sus empresas subsidiarias y al sistema diseñado en el ICC para apoyar los códigos y la industria regulatoria de los mismos.

\section{Key words}

Building Codes, International Code Council, regulatory documents, standards, United States.

\begin{abstract}
This paper will address the components of the International Code Council (ICC) as one of the most important organizations in terms of developing the model building codes for the US: the international codes. This membership-driven organization has the task of providing the building industry and all its stakeholders with the necessary regulatory documents, training, certification, plan check, product evaluation, and accreditation services to achieve safer and more sustainable building construction. This article provides an overview of the building codes in the U.S., the ICC and its subsidiaries, and ICC's systems designed to support the codes and the regulatory industry.
\end{abstract}

\section{INTRODUCTION}

First of all, it is important to note that building codes in the US were first developed by the insurance industry. Such codes are important to the insurance industry because its payout in the event of fires, earthquakes and damage in general tends to be substantial.

Three building codes, established by the Code Enforcement Officials, were used throughout the United States-BOCA, covered the northeast of the United States; ICBO covered everything on west of the United States including Alaska and Hawaii; and SBCCI covered the Southern part of the United States-until 1994, when these three organizations established the International Code Council. The process began in 1994 and it took until 2002 for the

${ }^{1}$ This article is based on a lecture by David Walls presented in the forum "Building Codes in Colombia: Approximations and implementation” held at Universidad de los Andes on September 8 $8^{\text {th }} 2014$. 
three organizations to consolidate into the ICC as a single unit.

\section{The INTERNATIONAL CODE COUNCIL}

The ICC's Mission and Vision are 1) to provide the highest quality codes, standards, products and services for all those concerned with the safety and performance of the built environment; and 2) to protect people's health, safety and welfare by creating better buildings and safer communities.

The ICC is a 52000 -member association dedicated to enforcing building safety and developing codes used to construct residential and commercial buildings throughout the U.S. and other countries around the world. It is a nonprofit organization headquartered in Washington D.C. with three regional offices: California, Alabama and Illinois. There are also a number of satellite offices in the state of Washington, in Utah and in Kansas. The organization has an annual budget of more than 70 million dollars, which fluctuates with the economy. It is self-funded so it doesn't receive any funds from any state or federal government or local government agencies. The body of staff is made up of approximately 300 engineers, architects and support staff. The ICC's subsidiaries are the International Code Council Foundation (ICCF), the ICC Evaluation Service (ICC ES), which are US leaders in the evaluation of building products for code compliance, and the International Accreditation Service (IAS) with their accreditation programs: building department, fabricator inspection, inspection agencies, product certification, agencies and testing labs and, more recently, an accreditation for commissioning agents.

\section{DEVELOPMENT OF ICC MODEL CODES}

A new edition of codes is published every three years. Changes are made during an open public hearing followed by a voting process known as the governmental consensus process. This process establishes that, despite the fact that everyone is invited to participate by proposing changes and commenting on subjects, in the end, it is only government personnel, who have no vested interest in the outcome of the code that can vote on its final version.

Building construction in the US is governed by coordinated codes and standards adopted as construction regulations, which cover building, plumbing, mechanical, fire, electrical, energy and, more recently, the international green construction code. There are a total of about 15 codes currently used.

Codes and Standards are developed by the private sector. In the US, the government does not actually develop the code. Rather, we have what are known as model codes, which are modified by local governments to design the regulations for their local government. As mentioned above, the Codes and Standards development process is dynamic and it includes the public and private sectors, which can be involved by proposing changes, but it is ultimately the public sector that votes.

The adoption of building construction regulations is primarily the rule of local and state government. One of my roles, when I worked for the state of California was to adapt the codes that are developed as a model code by the model code agencies-primarily International Green Construction Code (IGCC) - to make them specific to the State of California. Indeed, each state within the US draws up its own codes. To do this, some modify the model code, whereas others use the codes as they are without any modification.

The codes are designed to help ensure public safety, health and welfare in the built environment for which there are a number of minimum requirements such as the safety of life and property from fire and other hazards. The codes are concerned with a) the structural strength of a building, b) emergency exits, c) sanitation, d) light and ventilation, e) energy conservation, insofar as which the US has a particular energy code known as the green construction code, which goes beyond the energy conservation code to cover much more.

There is a family of 15 coordinated and correlated codes (Figure 1), which are the primary codes adapted throughout the United States and a number of other countries. These are: the International Building Code ${ }^{\circledR}$, International Fire Code ${ }^{\circledR}$, International Mechanical Code ${ }^{\circledR}$, International Plumbing Code ${ }^{\circledR}$, International Residential Code ${ }^{\circledR}$, International Energy Conservation Code ${ }^{\circledR}$, International Existing Building Code ${ }^{\circledR}$, International Fuel Gas Code ${ }^{\circledR}$, International Property Maintenance Code ${ }^{\circledR}$, International Private Sewage Disposal Code ${ }^{\circledR}$, International Zoning Code ${ }^{\circledR}$, International Wildland-Urban Interface Code ${ }^{\circledR}$, ICC Performance Code for Buildings and Facilities ${ }^{\circledR}$, International Green Construction Code ${ }^{\circledR}$, International Swimming Pool and Spa Code ${ }^{\circledR}$.

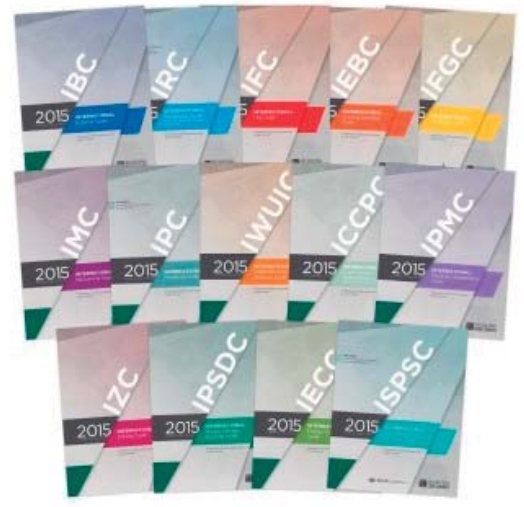

Figure 1. 2015 Codes Complete Collection. Source. ICC website.

ICC offers custom code services available to countries, states and local municipalities and it includes a complete publishing and distribution service. For example, the California Code is really the International Building Code modified by the State of California in all its areas: Building, Architectural, Structural, Fire, Health and Safety, to include everything that is specific to California including its specific laws. Another service the ICC offers is that of licensing intellectual property to third 
parties. While we have a lot of intellectual property or copyrighted property, we license it out for others to use parts of, should they wish to do so. ICC currently produces customized codes for more than 30 states and major jurisdictions. For example, if we go back to the state of California, it has its own statewide code, but the City of Los Angeles makes its own local amendments to the code to then publish it as its own Los Angeles City Code. The ICC also provides some custom support services such as training and technical publications. We've been able to work specifically with the different states to include whatever significant changes they have made to the model code to then publish their own technical document. As for training, we provide very specifically customized training for states and large local agencies.

\section{STANDARDS}

Codes reference more than 1000 standards, including American Society of Heating, Refrigerating and Air-Conditioning Engineers (ASHRAE), American Society for Testing and Materials (ASTM) and a variety of other standards created by different organizations for materials specifications, for design standards and testing standards. ASTM standards are the most widely used.

ICC Standards are developed through the American National Standards Institute (ANSI) process. The ICC ANSI A117.1, 2009 version includes: Accessible and Useable Buildings and Facilities, ensures that throughout the United States, there are facilities for persons with disabilities; and a Standard on the Design and Construction of Log Structures ICC 400 (2007) version, ICC 300 (2007) Bleachers, Folding and Telescoping Seating and Grandstands. In 2008, we developed an ICC Standard for the Design and Construction of Storm Shelters. So ICC is a standard developer organization along with ASTM and ASC and a number of the others; however, we don't focus on standards, but rather primarily on codes.

\section{CODES AND STANDARDS SUPPORT SERVICES}

As mentioned above, we have technical publications that facilitate an understanding of the codes and enhance their application. Some of the information in these publications may be confusing for someone that is, for example, a designer and is perhaps much more knowledgeable in a certain technical area than another. In such cases, these publications really help. They are also useful when it comes to enforcement, whereby local jurisdiction wants to undertake a plan review or they have to provide inspection services; in such cases, the publications provide some explanation as to what the code was. There are comparisons of various editions of the code and the historical information on the genesis of the requirements. Sometimes, it is very difficult to know why a specific provision within the code is there, it might not make sense, so the ICC provides that comparison, detailing what has changed, when it changed, and the genesis of that change; i.e., why it was required initially. ICC also offers professional interpretation of code requirements; that is, if the books or technical publications do not explain the issue, one can call ICC and there will be someone, whether it is an engineer, a fire services engineer, a mechanical engineer, or anyone who may have a specialty in an area, to help interpret the code. Finally, ICC provides plan review services, whereby if a local jurisdiction is overwhelmed, as many of them are, they can send ICC to undertake the plan review for any particular building.

ICC has communication tools such as a website with detailed information about all ICC functions, and future and past events; a building safety newsletter with a mailing distribution of 44000; and ICC eNews, which is an electronic newsletter with 220,000 subscribers.

\section{CODE COMMENTARIES}

A Code Commentary actually includes the code and comments right behind each section so that the full code and the commentary are provided all in one. As part of that commentary, it gives applications, examples of what one may need to apply, explanatory material, the code development history, it may also have illustrations for when the written instruction on how a connection is supposed to be made, an illustration may

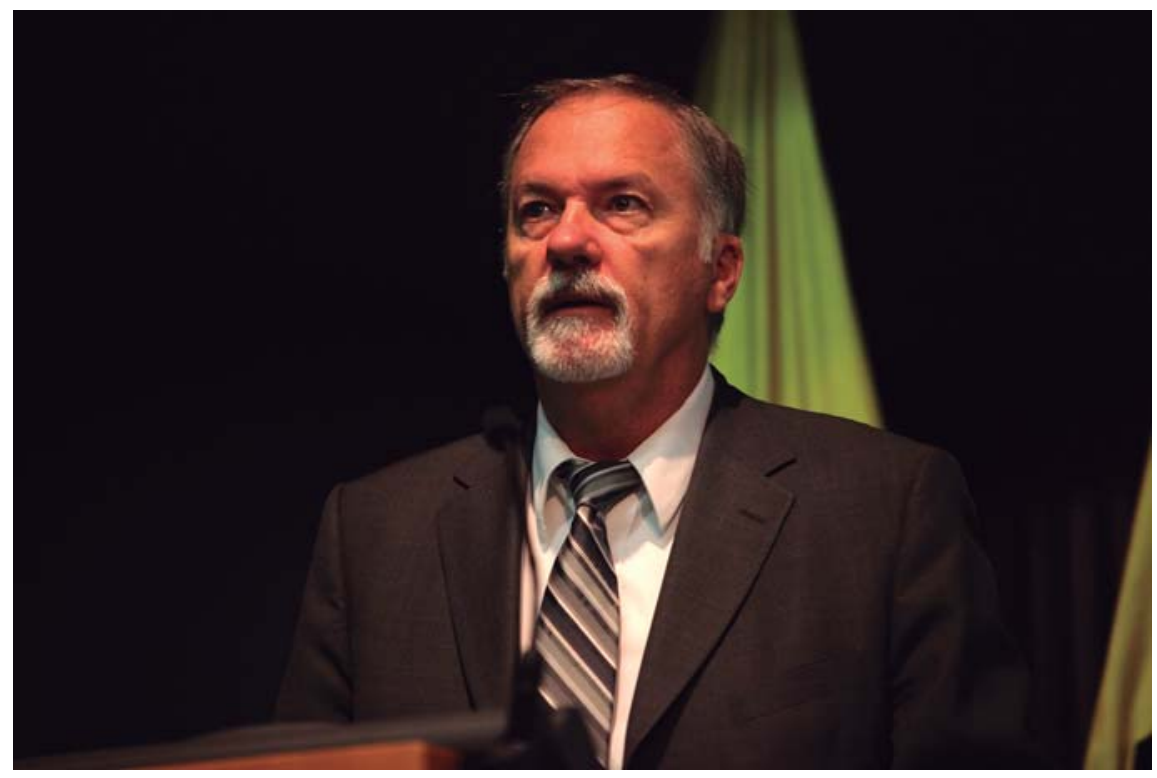

David Walls. Fuente: Archivo Particular, Universidad de los Andes 
help. A large bibliography of additional references is also provided to point readers to other sources if they cannot find the information they are looking for in the Code Commentary.

Information can be given over the telephone at any time; an average of 100,000 phone calls are attended annually. Over 5,000 informal written opinions are given by staff annually through internal peer review. A formal published position of the ICC is provided through a review committee, which, often, when an interpretation is a gray area, reviews and actually prints and publishes a formal position on that interpretation.

Standard support services and plan reviews are comprehensive reviews for designers and code officials. ICC provides a plan review worksheet and a conference professional report outlining code deficiencies, and, as mentioned above, assists local jurisdictions throughout the country in undertaking their plan review and inspection, which is required in all states of the United States.

\section{Certification and licensing SERVICES}

The certification of personnel ensures that competent individuals are involved in the building and regulatory process, and are familiar with the adopted codes. The ICC handles a number of certifications; however, they are considering condensing some of those. Being certified is a real advantage when one is working, looking for a job or showing one's proficiency. This certification eliminates the need for individual states and local agencies to design, implement, and maintain their own testing programs. So within the State of California, for example, there is a law that requires certification for building officials, building inspectors and plan checkers as well as fire officials. However, engineers, fire officials and some of the other architects also have to have their own professional license issued by the State of California.

Our training and education services ensure everyone involved in the building design, construction and code enforcement process is familiar with the adapted codes. This eliminates the need for individual states and local agencies to design, implement and maintain their own training programs and can be easily tailored to meet the needs of state and local agencies. We have even traveled to other countries, providing very specialized technical training and education services and we continue to do so. Training and education services conduct more than 300 seminars per year. Instructors are technical experts, with experience in code enforcement, so when somebody undertakes a training course with us, whether it is on fire, or on structural issues, she or he will be taught by individuals with solid technical expertise in all areas, in the code and also in its implementation.

There is an extensive curriculum directed toward professional growth, which offers services designed to assist State and local agencies. This is very important in terms of ensuring that the codes are implemented correctly, that they are applied correctly leading to the construction of safe buildings-including life safety, health safety, fire safety - and that are in line with sustainability regulations.

\section{ICC MEMBERSHIP SERVICES}

ICC provides a wide range of services all involved in the design, construction, operations and maintenance of buildings and enforcement of codes affecting buildings. Our primary members are governmental agencies but we do have many more that are in the professional industry such as architects, engineers, etc. Anyone in the building industry as a whole can become a member and benefits include toll free numbers and services, access, complimentary publications and unlimited use of all ICC support services.
Global consultation services are global programs that include assistance to countries in enhancing and improving their building regulatory systems, and to administer and enforce codes and standards effectively. We assist different countries with the creation of training, certification, and testing programs for code administrators, plan reviewers and inspectors. So a code administrator may be a building official, for example, who may oversee the overall process. In a small city, that may be the person that undertakes the inspection. In a large city, that person is definitely an administrator, who does not actually undertake plan review or inspections. As mentioned above, we assist in the development of customized building codes and standards, and also do that for the Global community. We also have laboratory accreditation programs.

ICC global services programs have been undertaken in Abu Dhabi, Saudi, Egypt, Afghanistan, Pakistan, Mexico, Caribbean and New Zealand.

\section{SCOPE OF THE INTERNATIONAL BUILDING CODE}

The International Building Code (IBC) provides minimal requirements to safeguard the public health, safety and general welfare of the occupants of new and existing buildings and structures. The IBC applies to all occupancies including 1 and 2 family dwellings and townhouses that are not part of the scope of the residential code mentioned earlier.

\section{REFERENCES}

International Code Council Website. http://www.iccsafe.org

International Code Council electronic newsletter. http://www.iccsafe.org/ news/ePeriodicals/subscribe.html 